\title{
PENERAPAN MODEL PEMBELAJARAN STUDENT TEAMS ACHIEVEMENT DIVISION UNTUK MENINGKATKAN HASIL BELAJAR PESERTA DIDIK KELAS VI C MIN 6 SUKOHARJO SEMESTER GASAL TAHUN PELAJARAN 2019/2020
}

\author{
JUMIYATI \\ Madrasah Ibtidaiyah Negeri 6 Sukoharjo \\ Email : Jumiyatiadzkia@gmail.com
}

\begin{abstract}
ABSTRAK
Tujuan penelitian ini adalah untuk meningkatkan prestasi belajar Ilmu Pengetahuan Alam materi penyesuaian makhluk hidup dengan lingkungannya siswa kelas VI C Madrasah Ibtidaiyah Negeri (MIN) 6 Sukoharjo pada Semester 1 Tahun Pelajaran 2019/2020 melalui model pembelajaran Student Teams Achievement Division (STAD). Penelitian ini merupakan penelitian tindakan kelas yang terdiri atas dua siklus dan setiap siklus terdiri dari dua pertemuan, dalam setiap siklus terdapat empat langkah yaitu perencanaan (planning), tindakan (acting), pengamatan (observating) dan refleksi (reflecting). Teknik pengumpulan data yaitu menggunakan observasi untuk mengamati aktifitas guru, aktitas peserta didik,dokumentasi untuk memperoleh data prestasi belajar IPA pada awal sedangkan tes digunakan untuk memperoleh data prestasi belajar siswa. Hasil penelitian menunjukkan peningkatan nilai ratarata pada kondisi awal 64,71 menjadi 72,50 dan77,,47 pada pertemuan ke-1-2 siklus I, 77,94,dan 85,94 pada pertemuan ke1-2 siklus II. Dilihat dari siswa yang tuntas KKM, pada kondisi awal 10 siswa atau 31,25\% meningkat menjadi 23 siswa atau 71,87,\%,27 atau 84,37\% pertemuan ke-1 siklus II ,meningkat lagi menjadi 28 atau 87,50\% pada pertemuan ke-1 siklus II dan 30 siswa atau 93,75\% pada pertemuan ke-2 siklus II. Secara kualitatif kemampuan peserta didik dalam memahami Ilmu Pengetahuan Alam materi penyesuaian makhluk hidup dengan lingkungannya meningkat dari kualifikasi rendah sedang tinggi Dari hasil penelitian tersebut nampak bahwa terjadi proses peningkatan prestasi belajar siswa dari sebelum tindakan, setelah tindakan siklus I maupun siklus II melalui model pembelajaran Student Teams Achievement Division. siswa kelas VI C Madrasah Ibtidaiyah Negeri (MIN) 6 Sukoharjo pada Semester 1 Tahun Pelajaran 2019/2020
\end{abstract}

Kata kunci : Penyesuaian Makhluk Hidup, Student Teams Achievement Division (STAD), Prestasi Belajar.

\section{PENDAHULUAN}

Madrasah Ibtidaiyah sebagai salah satu sarana untuk menghasilkan lulusan yang berkualitas (pengertian/PP Nomor 74 Tahun 2008 Tentang Guru) Hal tersebut merupakan tantangan bagi pelaku pendidikan (seorang guru) utamanya, untuk mencari sebab akibatnya demi tercapainya tujuan pengajaran sekaligus meningkatkan hasil belajar peserta didik. Upaya peningkatan pendidikan dapat dilakukan dari berbagai segi. Salah satu diantaranya dengan meningkatkan kualitas proses belajar mengajar siswa, agar potensi yang ada pada diri mereka dapat berkembang secara optimal. Penerapan model pembelajaran yang sesuai mengupayakan kemudahan siswa belajar sehingga tujuan instruksional pendidikan dapat tercapai.

Salah satu mata pelajaran yang ada di jenjang pendidikan dasar yang perlu ditingkatkan kualitasnya adalah Ilmu Pengetahuan Alam. Karena pendidikan dasar merupakan tempat yang pertama siswa mengenal konsep-konsep dasar Ilmu Pengetahuan Alam. Menurut Piaget yang dikutip Usman Samatowa (2006: 10) pola pikir anak usia sekolah dasar masih tergolong dalam kategori berpikir konkret. Dalam penyajian materi pembelajaran menuntut pengalaman langsung dalam hidup mereka. Oleh karena itu untuk mengurangi keabstrakan dalam berpikir, penyampaian materi hendaknya memerlukan model pembelajaran yang sesuai. Kenyataan di lapangan kadang-kadang guru menggunakan model pembelajaran yang kurang tepat. 
Salah satunya adalah mata pelajaran Ilmu Pengetahuan Alam penggunaan model pembelajaran yang kurang tepat, tidak memperjelas isi pesan bahkan akan membingungkan siswa. Perhatian siswa akan berubah dari kebutuhan belajar maupun bahan yang perlu diperlajari, pada hal lain yang mereka anggap lebih menarik. Hal yang demikian ini tidak diharapkan terjadi dalam proses belajar mengajar. Untuk itu pengajaran Ilmu Pengetahuan Alam yang diselenggarakan pada jenjang pendidikan dasar perlu mendapat perhatian mengingat pentingnya pengajaran IPA sebagai dasar untuk masuk jenjang sekolah yang lebih tinggi.

Kondisi pembelajaran Ilmu Pengetahuan Alam yang terjadi di kelas VI C Madrasah Ibtidaiyah Negeri (MIN) 6 Sukoharjo masih menggunakan metode yang berpusat pada guru. Guru lebih banyak menggunakan metode ceramah dan drill yang cenderung membosankan minat siswa. Oleh karena itu, siswa kurang tertarik terhadap pembelajaran. Hal tersebut terbukti dari perolehan nilai siswa yang masih di bawah Kriteria Ketuntasan Minimal (KKM). Nilai KKM yang harus dicapai siswa kelas VI pada mata pelajaran Ilmu Pengetahuan Alam yaitu 70. Dari 32 siswa, baru 10 siswa atau 31,25\% yang mendapat nilai minimal 70, sedangkan siswa yang mendapat nilai di bawah 70 sebanyak 22 siswa atau $68,75 \%$.

Untuk mengetahui hasil belajar kondisi awal ini dilakukan tes (evaluasi). Dari pengumpulan data hasil belajar IPA materi penyesuaian makhluk hidup dengan lingkungannya kondisi awal siswa kelas VIC Madrasah Ibtidaiyah Negeri (MIN) 6 Sukoharjo dapat disajikan tabel tingkat ketuntasan belajar siswa sebagai berikut :

Tabel 1. Ketuntasan Belajar Siswa Kondisi Awal (Pra siklus)

\begin{tabular}{|l|l|l|l|}
\hline No. & Ketuntasan & Jumlah & $\%$ \\
\hline 1. & Tuntas & 10 & $31,25 \%$ \\
\hline 2. & Belum Tuntas & 22 & $68,75 \%$ \\
\hline Jumlah & 32 & $100 \%$ \\
\hline Nilai Rata-rata & 65,71 \\
\hline Nilai Terendah & 36 & \\
\hline \multicolumn{2}{|l|}{ Nilai Tertinggi } & 95 & \\
\hline
\end{tabular}

Tes/Ulangan harian dilaksanakan Sabtu,3 Agustus 2019

Dilihat dari rata-rata kelas $(65,71)$ secara klasikal masih di bawah nilai Kriteria Ketuntasan Minimal untuk mata pelajaran Ilmu Pengetahuan Alam materi Penyesuaian Makhluk Hidup dengan Lingkungannya pada kelas VI C Madrasah Ibtidaiyah Negeri (MIN) 6 Sukoharjo yaitu 70. Untuk siswa yang tuntas baru 10 anak atau 31,25\%, sedangkan yang belum tuntas atau masih di bawah KKM sebanyak 22 anak atau 68,75\%. Dengan demikian dapat disimpulkan bahwa sebagian besar ketercapaian Kriteria Ketuntasan Materi (KKM) siswa kelas VI C dalam materi pelajaran IPA materi Penyesuaian Makhluk Hidup dengan Lingkungannya relatif masih rendah. Hal ini terjadi dikarenakan terdapat beberapa kendala, antara lain kurangnya antusias siswa dalam memahami materi dan kurang tepatnya model pembelajaran yang diterapkan. Berkenaan dengan kurangnya kompetensi siswa kelas VI C MIN 6 Sukoharjo dalam melakukan proses pemahaman IPA materi Penyesuaian Makhluk Hidup dengan Lingkungannya ini pada dasarnya merupakan salah satu dampak dari kurang tepatnya penerapan strategi pembelajaran IPA yang pada umumnya,saat proses pembelajaran guru cenderung menggunakan metode ceramah,drill,sehingga siswa kurang terlibat dalam proses pembelajaran,siswa tidak memperhatikn pelajaran dan siswa terlihat pasif.Beberapa siswa memang kelihatan memperhatikan ,namun juga tidak sedikit pula siswa yg beraktivitas sendiri.Pemecahan masalah yang digunakan adalah dengan melaksanakan pembelajaran dengan model Student Teams Achievement Division merupakan salah satu tipe pembelajaran kooperatif, dan salah satu model pembelajaran dengan mengkondisikan atau membagi perserta didik dalam satu kelompok yang heterogen,untuk bekerjasama menyelesaikan tugas, dengan salah satu anggota menjadi tutor sejawat.diskusikan bahan belajar LKS secara 
kolaboratif,sajian presentasi kelompok sehingga terjadi diskusi kelas,adanya kuis, sehingga mendorong siswa terbiasa bekerja sama dan saling membantu dalam menyelesaikan masalah,tetapi pada akhirnya bertanggung jawab secara mandiri. Dalam model ini, kegiatan belajar lebih berpusat pada siswa, sedangkan guru hanya berperan sebagai fasilitator dan mediator yang dinamis melalui pijakan pijakan yang bermakna.Pada akhir pbelajaran guru mengadakan evaluasi untuk menegtahui penguasaan siswa terhadapbahan/msteri yang telah dipelajari kemudian membuat skor individu dan tim untuk menentukan bentuk penghargaan.

Cara inilah yang dapat digunakan sebagai dasar pemecahan masalah yang ada, mengingat konsep penting dalam model pembelajaran Student Teams Achievement Division adalah: presentasi kelas (penyajian materi dari guru),kerja tim (tercipta kerjasama),Kuis atau tes tes setelah diberikan penyajian, skor kemampuan individual dan rekognisi tim (pengakuan usaha yg telah dilakukan kelompok) melalui perhitungan skor individu dan skor kelompok.(Salvin,2015)

\section{METODE PENELITIAN}

Proses pembelajaran dalam penelitian tindakan kelas ini dilaksanakan sebanyak siklus.setiap siklus terdari dari 2 kali pertemuan, yaitu pertemuan ke -1 (siklus 1), pertemuan ke-2 (siklus 1), pertemuan ke-1 (siklus 2) dan pertmuan ke -2 (siklus 2). Dan setiap siklus terdiri 4 rangkaian kegiatan, yaitu : (a) perencanaan, (b) tindakan, (c) pengamatan, (d) refleksi. dengan menggunakan Model Pembelajaran Student Team Achievement Divisionm

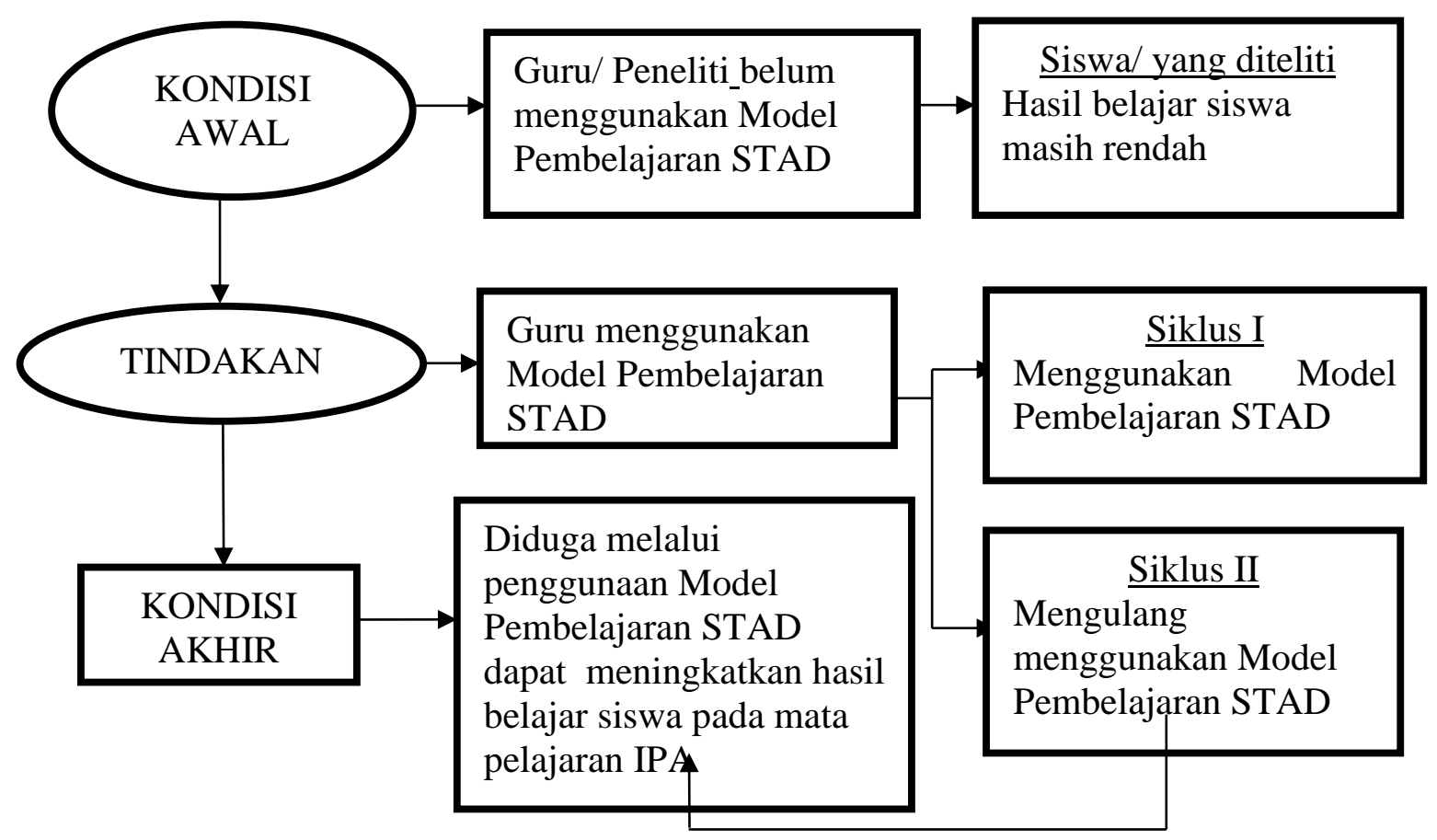

Gambar.1. Alur penerapan tindakan kelas.

Pada siklus pertama (siklus I) sesuai dengan skema yang telah ditetapkan dilakukan beberapa tahapan: tahap (1) Perencanaan Pada tahap ini peneliti membuat RPP, berkonsultasi dengan teman sejawat membuat instrumen. Pada tahap menyusun rancangan diupayakan ada kesepakatan antara guru dan sejawat. Rancangan dilakukan bersama antara peneliti yang akan melakukan tindakan dengan guru lain yang akan mengamati proses jalannya tindakan. Hal tersebut untuk mengurangi unsur subjektivitas pengamat serta mutu kecermatan pengamatan yang dilakukan. Tahap (2) Tahap Pelaksanaan tindakan dilakukan dengan pembelajaran di kelas. Pada tahap ini guru peneliti giat melakukan tindakan menggunakan metode Student Team Achievement Divisionm berbantuan alat peraga. Rancangan tindakan tersebut sebelumnya telah 
dilatih untuk dapat diterapkan di dalam kelas sesuai dengan skenarionya. Skenario dari tindakan diupayakan dilaksanakan dengan baik dan wajar. Tahap (3) Tahap observasi ini dilaksanakan bersamaan dengan waktu pelaksanaan. Tindakan yaitu saat proses belajar mengajar berlangsung, jadi, keduanya berlangsung dalam waktu yang sama. Pada tahap ini, guru yang bertindak sebagai peneliti melakukan pengamatan dan mencatat semua hal yang diperlukan dan terjadi selama pelaksanaan tindakan berlangsung. Pengumpulan data ini dilakukan dengan menggunakan belajar yang telah tersusun, termasuk juga pengamatan secara cermat pelaksanaan skenario tindakan dari waktu ke waktu serta dampaknya terhadap proses dan hasil belajar siswa, dan (4) Tahapan ini dimaksudkan untuk mengkaji secara menyeluruh tindakan yang telah dilakukan, berdasarkan data yang telah terkumpul, kemudian dilakukan evaluasi guna menyempurnakan tindakan berikutnya. Refleksi dalam PTK mencakup analisis, sintesis, dan penilaian terhadap hasil pengamatan atas tindakan yang dilakukan. Jika terdapat masalah dari proses refleksi maka dilakukan proses pengkajian ulang melalui siklus berikutnya yang meliputi kegiatan: perencanaan ulang, tindakan ulang, dan pengamatan ulang shingga permasalahan dapat teratasi.

Pada pelaksanaan siklus kedua (siklus II) proses pembelajaran yang dilakukan pada siklus ini meliputi : tahap (1) membuat RPP, berkonsultasi dengan teman sejawat membuat instrumen. Pada tahap menyusun rancangan diupayakan merupakan rancangan yang dibuat berdasarkan hasil perbaikan dari kelemahan pada siklus 1, tahap (2) melakukan tindakan berupa dilakukan dengan pembelajaran di kelas. Pada tahap ini guru peneliti giat melakukan tindakan menggunakan metode Student Team Achievement Divisionmdisertai alat peraga, (3) melakukan pengamatan yang meliputi mengobservasi aktivitas belajar peserta didik selama proses pembelajaran, mengevaluasi proses pembelajaran. Selanjutnya tahap (4) melakukan refleksi tentang hasil aktivitas belajar peserta didik selama proses pembelajaran dan post tes (tes hasil belajar) pada akhir siklus.

\section{HASIL DAN PEMBAHASAN}

\section{A. Hasil}

\section{Siklus I pertemuan pertama}

Pelaksanaan siklus I dilaksanakan pada hari Selasa 06 Agustus 2019. Guru masuk kelas pukul 08.00 WIB bersama observer. Kegiatan pembelajaran diawali dengan mengucapkan salam Siswa bertanya jawab dengan guru tentang Penyesuaian diri Tumbuhan dengan lingkungan habitatnya . Siswa dibagi dalam kelompok hetrogen (campuran menurut prestasi dan jenis kelamin).Masing masing kelompok mendapatkan wacana/tugas untuk mempelajari materi yang telah disiapkan oleh guru.Dalam kerja kelompok siswa saling berbagi tugas, saling membantu memberikan penyelesaian agar semua anggota-anggota kelompok dapat memahami materi(Berdasarkan habitatnya tumbuhan dibagi menjadi 3hidrofil,higrofit dan xerofit ), yang dibahas.Bila kelompok sudah menyelesaikan tugasnya secara keseluruhan, masing-masing kelompok menyampaikan hasilnya dan guru memberi klarifikasi.Guru mengadakan kuis secara individual untuk mengetahui sejauh mana keberhasilan belajar yang telah dicapai mengenai materi yang telah dibahas.Guru melakukan perhitungan skor perkembangan individu berdasarkan pedoman pemberian skor.Guru memantau perkembangan pemahaman tentang materi.Pada akhir siklus I, siswa mengerjakan tes formatif I.

Tabel 2. Ketuntasan Belajar Siswa pertemuan ke-1 Siklus I

\begin{tabular}{|l|l|l|l|}
\hline No. & Ketuntasan & Jumlah & $\%$ \\
\hline 1. & Tuntas & 23 & $71,87 \%$ \\
\hline 2. & Belum Tuntas & 9 & $28,13 \%$ \\
\hline Jumlah & 32 & $100 \%$ \\
\hline Nilai Rata-rata & 72,50 & \\
\hline Nilai Terendah & 45 & \\
\hline Nilai Tertinggi & 90 & \\
\hline
\end{tabular}


Berdasarkan pada tabel 1 di atas, dapat diketahui bahwa hasil belajar peserta didik kelas VI C yang mengikuti pembelajaran dengan penerapan Student Team Achievement Division. diperoleh nilai rata-rata hasil belajar IPA sebesar 72,50 dan ketuntasan belajar 71,87\% atau ada 23 peserta didik dari 32 peserta didik sudah tuntas belajar. Hasil ini menunjukkan bahwa secara klasikal peserta didik belum tuntas belajar, karena peserta didik yang memperoleh nilai $\geq 70(\mathrm{KKM})$ hanya sebesar $71,87 \%$ lebih kecil dari prosentase ketuntasan yang dikehendaki yaitu sebesar $80 \%$.

Berdasarkan hasil refleksi siklus pertama (siklus I) diketahui bahwa tidak tercapainya ketuntasan aktivitas belajar peserta didik dipengaruhi oleh beberapa hal yaitu: 1) anak belum terbiasa dalam melaksanakan model pembelajaran, 2) masih terdapat peserta didik yang pasif mengikuti pembelajaran seperti kurangnya keinginan peserta didik untuk bertanya dan menjawab pertanyaan guru. Oleh karena itu peneliti merasa perlu melakukan perbaikan tindakan terhadap proses pembelajaran yang telah dilakukan pada siklus pertama (siklus I) dengan lebih mendekatkan memotivasi kepada peserta didik, guru memberikan contoh memaparkan materi kepada siswa yang merasa kesulitan dalam melakukan presentasi, di samping itu guru membantu peserta didik secara intensif terutama peserta didik yang pasif.

\section{Siklus I pertemuan kedua}

Pelaksanaan pertemuan ke-2 siklus I dilaksanakan pada hari Senin 12 Agustus 2019. Guru masuk kelas pukul 08.00 WIB bersama observer. Guru menyampaikan pembelajaran sesuai dengan rencana perbaikan pelaksanaan pembelajaran yang telah disusun.Guru menyampaikan materi dengan menjelaskan peta konsep tumbuhan yang menyesuaikan dengan lingkungannya yaitu :Ciri-ciri tumbuhan yang hidup di gurun dan di air,Contoh tumbuhan dalam menyesuaikan diri dengan lingkungan,,Cara tumbuhan menyesuaikan diri dari musuhnya,Ciri khusus pada beberapa tumbuhan untuk melindungi dirinya, misalnya memiliki racun, duri, atau daun yang tajam,menghasilkan getah,memiliki rambut.Guru memberikan yelyel dan tepuk tangan di sela-sela pembelajaran agar siswa lebih termotivasi dan bersemangat dalam pembelajaran serta tidak jenuh atau bosan.Guru meminta siswa untuk membentuk kelompok hetrogen (campuran menurut prestasi dan jenis kelamin),Bersama kelompoknya, siswa berdiskusi tentang penyesuaian makhluk hidup khususnya tumbuhan dengan lingkungannya(Penyesuaian /cara cara tumbuhan melindungi diri), Wakil dari setiap kelompok secara bergantian maju untuk menyampaikan hasil diskusi kelompoknya, Membahas hasil diskusi kelompok secara klasikal, Guru melakukan bimbingan pada setiap kelompok,Siswa yang menyelesaikan tugas dengan cepat, tepat, dan benar dipersilakan maju ke depan kelas untuk melaporkan hasilnya,Siswa bersama guru menyimpulkan materi pelajaran,Pada akhir pertemuan ke-2 siklus I siswa mengerjakan tes formatif kemudian guru mengadakan penilaian dan menganalisis hasil tes formatif.Berdasarkan hasil pengamatan/observasi dan hasil tes selama proses pembelajaran Siklus I dapat dilihat pada Tabel berikut :

Tabel 3. Ketuntasan Belajar Siswa Pertemuan ke-2 Siklus I

\begin{tabular}{|l|l|l|l|}
\hline No. & Ketuntasan & Jumlah & $\%$ \\
\hline 1. & Tuntas & 27 & $84,37 \%$ \\
\hline 2. & Belum Tuntas & 5 & $15,62 \%$ \\
\hline Jumlah & 32 & $100 \%$ \\
\hline Nilai Rata-rata & 77,47 & \\
\hline Nilai Terendah & 50 & \\
\hline \multicolumn{2}{|l}{ Nilai Tertinggi } & 100 & \\
\hline
\end{tabular}

Dilihat dari rata-rata kelas $(77,47)$ secara klasikal sudah di atas nilai Kriteria Ketuntasan Minimal untuk mata pelajaran IPA pada kelas VI C Madrasah Ibtidaiyah Negeri (MIN) 6 Sukoharjo yaitu 70. Untuk siswa yang tuntas sebanyak 27 anak atau 84,37\%, sedangkan yang 
belum tuntas sebanyak 5 anak atau 15,62\%. Melihat kondisi tersebut berarti sebagian besar peserta didik sudah ada peningkatan hasil belajarnya, bahkan ada beberapa siswa yang memperoleh nilai 100.Peningkatan hasil belajar ini didukung oleh berbagai faktor, antara lain :Kekurangan pada siklus sebelumnya sudah mengalami perbaikan dan peningkatan.Peserta didik lebih kompak dan aktif dalam proses pembelajaranSelama proses belajar belajar guru telah melaksanakan pembelajaran dengan baik. Meskipun ada beberapa aspek yang belum sempurna, dalam pengondisian kelas guru masih belum maksimal karena siswa kelas VI tergolong anak yang masih suka bermain, di mana usia tersebut dalam melaksanakan diskusi masih sulit berkonsentrasi, sehingga terkadang masih dibantu oleh guru mitra dan pengelolaan diskusi.

\section{Siklus II pertemuan pertama}

Pelaksanaan pertemuan I sikulus 2 dilaksanakan pada hari Selasa 20 Agustus 2019. Guru masuk kelas pukul 08.00 WIB bersama observer. Kegiatan pembelajaran diawali dengan mengucapkan salam,guru menanyakan kehadiran murid. Pada kegiatan inti Siswa bertanya jawab dengan guru tentang tentang materi yaitu Ciri ciri hewan dan habitatnya (bentuk penyesuaian diri hewan terhadap lingkungan dalam memperoleh makanan,mempertahankan diri dari mangsa, juga penyesuaian diri terhadap kondisi habitat yang ekstrim. Siswa dibagi dalam kelompok hetrogen (campuran menurut prestasi dan jenis kelamin).

Masing masing kelompok mendapatkan wacana/tugas untuk mempelajari materi yang telah disiapkan oleh guru. Dalam kerja kelompok siswa saling berbagi tugas, saling membantu memberikan penyelesaian agar semua anggota-anggota kelompok dapat memahami materi yang dibahas. Bila kelompok sudah menyelesaikan tugasnya secara keseluruhan, masing-masing kelompok menyampaikan hasilnya dan guru memberi klarifikasi. Guru mengadakan kuis secara individual untuk mengetahui sejauh mana keberhasilan belajar yang telah dicapai mengenai materi yang telah dibahas. Guru melakukan perhitungan skor perkembangan individu berdasarkan pedoman pemberian skor. Guru memantau perkembangan pemahaman tentang materi. Pada akhir siklus I, siswa mengerjakan tes formatif I. Berdasarkan hasil pengamatan/observasi dan hasil tes selama proses pembelajaran Siklus I dapat dilihat pada Tabel 4.

Tabel 4. Ketuntasan Belajar Siswa Pertemuan ke-1 Siklus II

\begin{tabular}{|l|l|l|l|}
\hline No. & Ketuntasan & Jumlah & $\%$ \\
\hline 1. & Tuntas & 28 & $87,50 \%$ \\
\hline 2. & Belum Tuntas & 4 & $12,50 \%$ \\
\hline Jumlah & 32 & $100 \%$ \\
\hline Nilai Rata-rata & 77,97 & \\
\hline Nilai Terendah & 50 & \\
\hline Nilai Tertinggi & 95 & \\
\hline
\end{tabular}

Dilihat dari rata-rata kelas $(77,97)$ secara klasikal sudah di atas nilai Kriteria Ketuntasan Minimal untuk mata pelajaran IPA pada kelas VI Madrasah Ibtidaiyah Negeri (MIN) 6 Sukoharjo yaitu 70. Untuk siswa yang tuntas sebanyak 28 anak atau 87,50\%, sedangkan yang belum tuntas sebanyak 4 anak atau 12,50\%. Melihat kondisi tersebut berarti sebagian besar peserta didik sudah ada peningkatan hasil belajarnya, bahkan ada beberapa siswa yang memperoleh nilai 95.

Dilihat dari rata-rata kelas $(77,97)$ secara klasikal sudah di atas nilai Kriteria Ketuntasan Minimal untuk mata pelajaran IPA pada kelas VI Madrasah Ibtidaiyah Negeri (MIN) 6 Sukoharjo yaitu 70. Untuk siswa yang tuntas sebanyak 28 anak atau 87,50\%, sedangkan yang belum tuntas sebanyak 4 anak atau 12,50\%. Melihat kondisi tersebut berarti sebagian besar peserta didik sudah ada peningkatan hasil belajarnya, bahkan ada beberapa siswa yang memperoleh nilai 95. Peningkatan hasil belajar ini didukung oleh berbagai faktor, antara lain : 
Kekurangan pada siklus sebelumnya sudah mengalami perbaikan dan peningkatan.Peserta didik lebih kompak dan aktif dalam proses pembelajaran. Selama proses belajar belajar guru telah melaksanakan pembelajaran dengan baik. Meskipun ada beberapa aspek yang belum sempurna, dalam pengondisian kelas guru masih belum maksimal karena siswa kelas VI tergolong anak yang masih suka bermain, di mana usia tersebut dalam melaksanakan diskusi masih sulit berkonsentrasi, sehingga terkadang masih dibantu oleh guru mitra dan pengelolaan diskusi.

\section{Siklus II pertemuan kedua}

Pelaksanaan siklus 2 pertemuan ke-2 dilaksanakan pada hari Rabu 28 Agustus 2019. Guru masuk kelas pukul 08.00 WIB bersama observer. Kegiatan pembelajaran diawali dengan mengucapkan salam. Guru menyampaikan pembelajaran sesuai dengan rencana perbaikan pelaksanaan pembelajaran yang telah disusun. Guru menyampaikan materi dengan menjelaskan peta konsep Cara cara hewan hewan untuk melindungi diri yaitu : (Kamulfase, Mimikri, Autotomi) Menggulungkan diri, Mengeluarkan kelenjar bau, Mengeluarkan bisa dan sengat,Berpura pura mati, Mengeluarkan cairan seperti tinta,Penyesuaian hewan terhadap kondisi ekstrim di kutub, gurun dan di air. Guru memberikan yel-yel dan tepuk tangan di selasela pembelajaran agar siswa lebih termotivasi dan bersemangat dalam pembelajaran serta tidak jenuh atau bosan. Guru meminta siswa untuk membentuk kelompok hetrogen (campuran menurut prestasi dan jenis kelamin), bersama kelompoknya, siswa berdiskusi tentang penyesuaian makhluk hidup khususnyaciri ciri hewan berdasarkan habitatnya, Wakil dari setiap kelompok secara bergantian maju untuk menyampaikan hasil diskusi kelompoknya, Membahas hasil diskusi kelompok secara klasikal, Guru melakukan bimbingan pada setiap kelompok, Siswa yang menyelesaikan tugas dengan cepat, tepat, dan benar dipersilakan maju ke depan kelas untuk melaporkan hasilnya, Siswa bersama guru menyimpulkan materi pelajaran, Pada akhir pertemuan ke-2 siklus II siswa mengerjakan tes formatif kemudian guru mengadakan penilaian dan menganalisis hasil tes formatif.

\section{Tabel 5. Ketuntasan Belajar Siswa Pertemuan ke-2 Siklus II}

\begin{tabular}{|l|l|l|l|}
\hline No. & Ketuntasan & Jumlah & $\%$ \\
\hline 1. & Tuntas & 30 & $93,75 \%$ \\
\hline 2. & Belum Tuntas & 2 & $6,25 \%$ \\
\hline Jumlah & 32 & $100 \%$ \\
\hline Nilai Rata-rata & 85,94 & \\
\hline Nilai Terendah & 60 & \\
\hline Nilai Tertinggi & 100 & \\
\hline
\end{tabular}

Dilihat dari rata-rata kelas $(85,94)$ secara klasikal sudah di atas nilai Kriteria Ketuntasan Minimal untuk mata pelajaran IPA pada kelas VI C Madrasah Ibtidaiyah Negeri (MIN) 6 Sukoharjo yaitu 70. Untuk siswa yang tuntas sebanyak 30 anak atau 93,75\%, sedangkan yang belum tuntas sebanyak 2 anak atau 6,25\%. Melihat kondisi tersebut berarti sebagian besar peserta didik sudah ada peningkatan hasil belajarnya, bahkan ada beberapa siswa yang memperoleh nilai 100. Maka penelitian ini berakhir di siklus kedua 2. Perbandingan hasil belajar peserta didik pada sikus 1 dengan siklus 2 ditunjukkan pada Tabel 3. 
Tabel 6. Perbandingan hasil belajar peserta didik pada siklus 1 dan siklus 2

\begin{tabular}{|c|c|c|c|c|c|}
\hline No. & Uraian & $\begin{array}{c}\text { Hasil } \\
\text { Siklus } \\
1(1)\end{array}$ & $\begin{array}{c}\text { Hasil } \\
\text { Siklus } \\
\text { I(2) }\end{array}$ & $\begin{array}{c}\text { Hasil } \\
\text { Siklus } \\
\text { II(1) }\end{array}$ & $\begin{array}{c}\text { Hasil } \\
\text { Siklus II(2) }\end{array}$ \\
\hline 1. & Nilai Tertinggi & 90 & 100 & 95 & 100 \\
\hline 2. & Nilai Terendah & 45 & 50 & 50 & 60 \\
\hline 3. & $\begin{array}{l}\text { Nilai rata-rata tes hasil } \\
\text { belajar }\end{array}$ & 72.60 & 77,47 & 77,97 & 85,94 \\
\hline 4. & $\begin{array}{l}\text { Jumlah peserta didik yang } \\
\text { tuntas belajar }\end{array}$ & 23 & 27 & 28 & 30 \\
\hline 5. & $\begin{array}{l}\text { Jumlah peserta didik yang } \\
\text { tidak tuntas }\end{array}$ & 9 & 5 & 4 & 2 \\
\hline 6. & $\begin{array}{l}\text { Persentase ketuntasan } \\
\text { belajar }\end{array}$ & $71,81 \%$ & $84,37 \%$ & $87,50 \%$ & $93,75 \%$ \\
\hline
\end{tabular}

Berdasarkan pada tabel di atas, dapat diketahui bahwa hasil belajar peserta didik kelas VI C yang mengikuti pembelajaran dengan penerapan model pembelajaran Student Team Achievement Division mengalami peningkatan dari siklus I ke Siklus 2 sebesar 8,47\% dari ratarata 77,47 pada siklus I menjadi 85,94 pada siklus II. Sedangkan ketuntasan klasikal mengalami peningkatan sebesar 9,38\% dari KK 84,37\% menjadi KK 93,75\% pada siklus II.

\section{B. Pembahasan}

Hasil kemampuan memahami penyesuaian tumbuhan dengan habitatnya yang merupakan tes unjuk kerja memforsir siswa untuk betul-betul dapat memahami apa yang sudah dipelajari. Nilai rata-rata siswa di siklus I sebesar pertemuan pertama 72,60, dengan ketuntasan klasikal sebesar 71,87\%, menunjukkan bahwa siswa telah menguasai materi yang diajarkan walaupun belum begitu sempurna. Hasil ini belum menunjukkan peningkatan kemampuan siswa menguasai mata pelajaran Penyesuaian makhluk hidup dengan lingkungannya dengan pokok bahasan memahami penyesuaian tumbuhan dengan habitatnya apabila dibandingkan dengan nilai awal siswa sesuai data yang sudah disampaikan dalam analisis sebelumnya.

Hasil kemampuan memahami penyesuaian diri (cara-cara) tumbuhan untuk melindungi diri dengan yang merupakan tes unjuk kerja yang keras siswa untuk betul-betul dapat memahami apa yang sudah dipelajari. Nilai rata-rata siswa di siklus I pertemuan kedua sebesar 77,47 , dengan ketuntasan klasikal sebesar $84,37 \%$, menunjukkan bahwa siswa telah menguasai materi yang diajarkan, namun pada pelaksanan presentasi anak anak masih banyak yang kurang aktif, belum begitu sempurna. Hasil ini sudah sedikit peningkatan kemampuan siswa menguasai mata pelajaran Penyesuaian makhluk hidup dengan lingkungannya dengan pokok bahasan memahami penyesuaian diri (cara-cara) tumbuhan untuk melindungi diri.

Hasil kemampuan memahami penyesuaian tumbuhan dengan habitatnya di siklus I telah menemukan efek utama bahwa penggunaan metode tertentu akan berpengaruh terhadap hasil belajar siswa. Metode dipilih sebagai jembatan atau media transformasi pembelajaran terhadap tujuan yang ingin dicapai (Sunhaji,2015) Dengan demikian, tujuan pembelajaran menuntut adanya pemilihan metode yang relevan dalam praktik pembelajaran (Sunhaji, 2015).

Seperti telah diketahui bersama bahwasannya mata pelajaran IPA menitikberatkan pembelajaran pada aspek kognitif, afektif, dan psikomotor sebagai pedoman prilaku kehidupan sehari-hari siswa. Untuk penyelesaian kesulitan yang ada maka penggunaan metode ini dapat membantu siswa untuk, bertindak aktif, bertukar pikiran, mengeluarkan pendapat, bertanya, berdiskusi, berargumentasi, bertukar informasi dan memecahkan masalah yang ada bersama dengan anggota kelompok diskusinya. Hal inilah yang membuat siswa berpikir lebih tajam, lebih kreatif dan kritis sehingga mampu untuk memecahkan masalah-masalah yang kompleks dan efek selanjutnya adalah para siswa akan dapat memahami dan meresapi mata pelajaran IPA lebih jauh. Kendala yang masih tersisa yang perlu dibahas adalah kemampuan memahami penyesuaian 
tumbuhan dengan habitatnya yang dicapai pada siklus I ini sudah memenuhi harapan sesuai dengan tuntutan KKM mata pelajaran seni budaya di sekolah ini yaitu sebesar 70,tetapi hasilnya belum maksimal. Oleh karenanya upaya perbaikan lebih lanjut masih perlu diupayakan sehingga perlu dilakukan perencanaan yang lebih matang untuk siklus selanjutnya.

Hasil yang diperoleh dari kemampuan memahami peyesuaian diri hewan dengan lingkungannya di siklus II menunjukkan bahwa kemampuan siswa dalam mengikuti pelajaran sudah cukup baik. Ini terbukti dari rata-rata nilai siswa mencapai 77,97, dengan ketuntasan klasikal $87,50 \%$. Pada pertemuan pertama siklus 2 . Juga hasil yang diperoleh dari kemampuan memahami penyesuaian diri hewan untuk mempertahankan/melindungi diri menunjukkan bahwa kemampuan siswa dalam mengikuti pelajaran sudah cukup baik. Ini terbukti dari rata-rata nilai siswa mencapai 85,94, dengan ketuntasan klasikal 93,75\%. Pada pertemuan kedua siklus 2. Hasil ini menunjukkan bahwa model Student Team Achievement Division telah berhasil meningkatkan kemampuan siswa menempa ilmu sesuai harapan. Student Team Achievement Division merupakan model yang cocok bagi siswa apabila guru menginginkan mereka memiliki kemampuan berkreasi, berargumentasi, mengeluarkan pendapat secara lugas, bertukar pikiran, berargumentasi, mengingat penggunaan metode ini adalah untuk memupuk kemampuan intelektual siswa, mendorong siswa untuk mampu menemukan sendiri, menempatkan siswa pada posisi sentral dan mengupayakan agar siswa tidak belajar dengan menghafal. Dari hasil penelitian menunjukkan adanya peningkatan hasil nilai awal, nilai siklus I(pertemuan 1-2) dan nilai siklus II(pertemuan 1-2), yaitu dari rata-rata nilai awal(pra siklus) adalah 65,71 naik di siklus I menjadi 72,60 pertemuan pertama 77,47 pertemuan kedua dan di siklus II naik menjadi 77,97 pertemun pertama dan 85,94 pertemuan kedua. Untuk ketuntasan klasikal juga mengalami kenaikan dari $31,25 \%$ (pra siklus) pada siklus I menjadi $71,87 \%$ pertemua pertama dan $84,37 \%$ pada pertemuan kedua menjadi $87,50 \%$ pertemuan pertama dan $85,94 \%$ pertemuan kedua siklus II. Hal ini sejalan pula dengan temuan-temuan peneliti lain seperti yang dilakukan oleh Inten (2004) dan Puger (2004) yang pada dasarnya menyatakan bahwa metode pembelajaran yang diterapkan berpengaruh terhadap hasil belajar siswa. Dengan demikian dapat dikatakan penerapan model pembelajaran Student Team Achievement Division dapat meningkatkan hasil belajar dan memahami penyesuaian makhluk hidup dengan lingkungannya di kelas. Pembelajaran model Student Team Achievement Division sangat membantu guru meningkatkan kualitas pembelajaran di kelas terutama dalam mengajarkan materi memahami penyesuaian makhluk hidup dengan lingkungannya maupun materi lainnya.

\section{PENUTUP}

Sesuai hasil penelitian dan pembahasan, maka dapat dikemukakan bahwa setelah dilakukan tindakan dengan menggunakan penerapan Student Team Achievement Division pada peserta didik kelas VI C MIN 6 Sukoharjo semester ganjil tahun pelajaran 2019/2020 terjadi perubahan penguasaan mata pelajaran IPA materi penyesuaian makhluk hidup dengan lingkungannya. Perubahan ini nampak pada hasil observasi maupun pos test yang didapat dari pra tindakan, tindakan pada siklus I (pertemuan 1-2), dan tindakan dari siklus II (pertemuan 12). Data perkembangan hasil peningkatan hasil belajar peserta didik dapat dilihat dari rata-rata perolehan nilai peserta didik pada masing-masing siklus mengalami peningkatan yakni pada nilai awal (pra siklus) adalah 65,71 naik di siklus I menjadi 72,60 pertemuan pertama 77,47 pertemuan kedua dan di siklus II naik menjadi 77,97 pertemun pertama dan 85,94 pertemuan kedua. Untuk ketuntasan klasikal juga mengalami kenaikan dari 31,25\% (pra siklus) pada siklus I menjadi $71,87 \%$ pertemua pertama dan $84,37 \%$ pada pertemuan kedua menjadi $87,50 \%$ pertemuan pertama dan $85,94 \%$ pertemuan kedua siklus II ada 2 siswa yang hasil belajarnya belum tuntas KKM, hal ini perlu adanya perlakuan khusus terhadap kedua siswa tersebut.Dengan hasil penelitian ini, penulis menyarankan kiranya teman teman guru yang lain dapat mencoba menerapkan model pembelajaran Student Team Achievement Division pada materi lain yang lebih kompleks. 
DAFTAR PUSTAKA

Candra dan Syahrum. (2012). Penelitian Tindakan Kelas (Konsep dan Penerapan Dalam Ruang-Ruang Kelas). Medan: Latansa Press.

Djojosoediro, Wasih. (2008). Pengembangan dan Pembelajaran IPA SD. Bandung : Refika Aditama.

Ngalimun, dkk. (2015). Strategi dan Model Pembelajaran. Banjarmasin : Aswaja Pressindo. Puger, I Gusti Ngurah. (2004). Belajar Kooperatif. Diktat Perkuliahan Mahasiswa Unipas.

Salim dan Syahrum. (2012). Metodologi Penelitian Kualitatif. Medan : Citapustaka Media.

Samatowa, Usman. (2006). Bagaimana Membelajarkan IPA di Sekolah Dasar. Jakarta: Depdiknas.

Sanjaya, Wina. (2009). Penelitian Tindakan Kelas, Jakarta: Prenada Media Grup.

Slavin Robet,E. (2015). Cooperative Learning. Bandung:Nusa Media

Sunhaji. (2015). Strategi Pembelajaran Konsep Dasar, Metode dan Aplikasi dalam Proses Belajar Mengajar. Pustaka Sanja

Suprijono, Agus. (2009). Cooperative Learning. Yogyakarta: Pustaka Pelajar,

Warsono dan Hariyanto. (2003. Undang-Undang Republik Indonesia Nomor 20 Tahun 2003 tentang Sistem Pendidikan Nasional. Jakarta: Departemen Pendidikan Nasional Republik Indonesia.

Warsono dan Hariyanto. (2012). Pembelajaran Aktif Teori dan Asesmen. Surabaya: Remaja Rosdakarya 